\author{
Ariel Ciechański \\ $\mathrm{dr}$ \\ Instytut Geografii i przestrzennego \\ Zagospodarowania im. St. \\ Leszczyckiego PAN \\ ariel@twarda.pan.pl
}

DOI: $10.35117 /$ A_ENG_17_01_01

\title{
The narrow-gauge heritage railways - opportunities and threats. Polish achievements in comparison to the experiences of the neighboring countries
}

\begin{abstract}
Heritage railways are very important component of local economies and transport in many European countries. Unfortunately, this segment of the tourism market in Poland seems to be still regarded as almost non-existent or often superfluous.

Meanwhile, our country entered in the new economic and political conditions with technically underdeveloped rail with its archaic rolling-stock not only in comparison to railways in western countries, but also to some of the countries of the former socialist bloc. There was observed of hundreds working steam locomotives and dozens of narrow gauge railways in every day freight and passenger services. It should be noted that from the perspective of 25 years of transformation, unfortunately, this heritage was mostly lost.

Number of still active steam locomotives from year to year drastically decreased. Many very interesting narrow-gauge railways was closed and scrapped. This disquieting trend unfortunately is still observed and there are barriers in development of this kind of tourist attractions which can make the future of even existing heritage railways uncertain. It is therefore necessary to compare Polish experiences with similar from neighboring countries like Czech Republic and Slovakia.
\end{abstract}

Keywords: Narrow-gauge railways; Railway tourism; Transformation-economic and political system

\section{Introduction}

The use of tourist facilities related to the cultural heritage of railway transport in many European countries is an important component of local economies. For example, historic railways in the United Kingdom were visited in 2002 by 5.4 million visitors, generating revenues of $£ 39$ million and providing employment for nearly 1,100 people. [3] The German branch of the VDMT is home to about a hundred museums and museums railways, but there are a lot more historic railway rolling stock in the country - in 2000 there were 440 such entities in Germany [5]. Unfortunately, in Poland one can get the impression that this segment of the tourist market is still regarded as almost non-existent. In 2011, there were almost 30 narrow gauge railways with a total length of $480 \mathrm{~km}$ and more than 25 open air museums, railway museums and traditional chapels - some of them were already permanently or temporarily unavailable [2].

This article will explore the use of facilities related to the history of narrow gauge railways operating from the mid 1970s until the present as tourist attractions in Poland. For comparison, the use of narrow-gauge railways in daily traffic in the Czech Republic, Germany and Switzerland is highlighted. Also discussed are the examples of the process of shaping this type of attraction in the Czech Republic and Slovakia, and also refer to the Russian experience. as lying on the opposite pole. 
On the basis of the analysis, which also includes shortened case studies in Poland and abroad, conclusions are drawn about the opportunities and threats posed by such objects and presents potential solutions to the problems..

\section{Tourist use of narrow-gauge railways before separation from the structure of PKP company}

Prior to the economic and political transformation, the use of the technical heritage of the railways in Poland in tourism was mainly directed to the establishment of the Warsaw Railway Museum set up in 1972. In the same year, the Narrow Gauge Railway Museum in Venice (Branch of the Regional Museum in Bydgoszcz) was launched, followed by the tourist trains in Żnin-Wenecja-Gąsawa in 1976. Moreover, the tourist transport was provided by the Bieszczady Forest Railway, but it was an activity accompanying the transport of wood. In the early nineties to this group joined Sochaczewska rail given the use of the Warsaw Railway Museum. At the same time it is important to remember that narrow-gauge railways still played their original role, though due to the growing crisis in a much more limited way. However, the new conditions of the economy were technically late, as a kind of open-air museum (Photo 2). This made it possible to adapt them to the needs of tourists at a relatively low cost. Hence, in response to declining demand, the introduction of scheduled and nonpartisan tourism has begun. The lack of marketing experience among the railwaymen, however, made it particularly notable that the first offer did not produce the expected economic results.Narrow-gauge railways in Poland have survived in normal operation until 2001, when PKP SA suspended the passenger traffic in summer and in the autumn also included in its network all the networks of its type. In the next 2-3 years a battle ensued to save at least some of them. Act on Restructuring, Commercialization of PKP Privatization [13] allowed free transfer of assets to the self-governments of all three levels. The lovers of railways have managed to encourage some local governments to take over the narrow-gauge railway. Typically they were first handed over to the rolling stock, while the property was for the unsettled legal situation only in lending. In the case of the railway parts, unfortunately, for 15 years after the cessation of their normal operation, the ownership issues have still not been settled and although they are in the possession of local governments, they still belong to PKP SA. A large group of railways unfortunately did not manage to develop. They were abandoned, devastated and then largely physically abolished.

In the present situation, it was necessary to develop new operators of narrow-gauge railway in Poland. Z. Taylor and A. Ciechański [12] distinguish three basic types of railway carriers:

I. non-governmental organizations (NGOs): associations, foundations, railroad enthusiasts or members of local communities,

II. organizational units of self-governments or companies created by local governments, where the tourist railway is located,

III. other entities, i.e. private companies, institutions or companies not affiliated with local government.

It seems that the process of restoring to the narrow gauge railway has been practically completed. In spite of attempts to exploit them in normal passenger and freight traffic, the only function that is finally adopted is the tourist function.

\section{Narrow-gauge tourist and museum railways after the restructuring of PKP}

Unlike what we observe in Germany, the United Kingdom, or even the Czech Republic, tourist attractions related to the technical heritage of narrow-gauge railways in Poland are still a domain of the public sector. Many active lines are still owned by PKP SA, and local 
governments do not use lenders until ownership is settled. There are also railroads such as rogowska or żuławska, which are handed over to local self-governments (fig. 1).

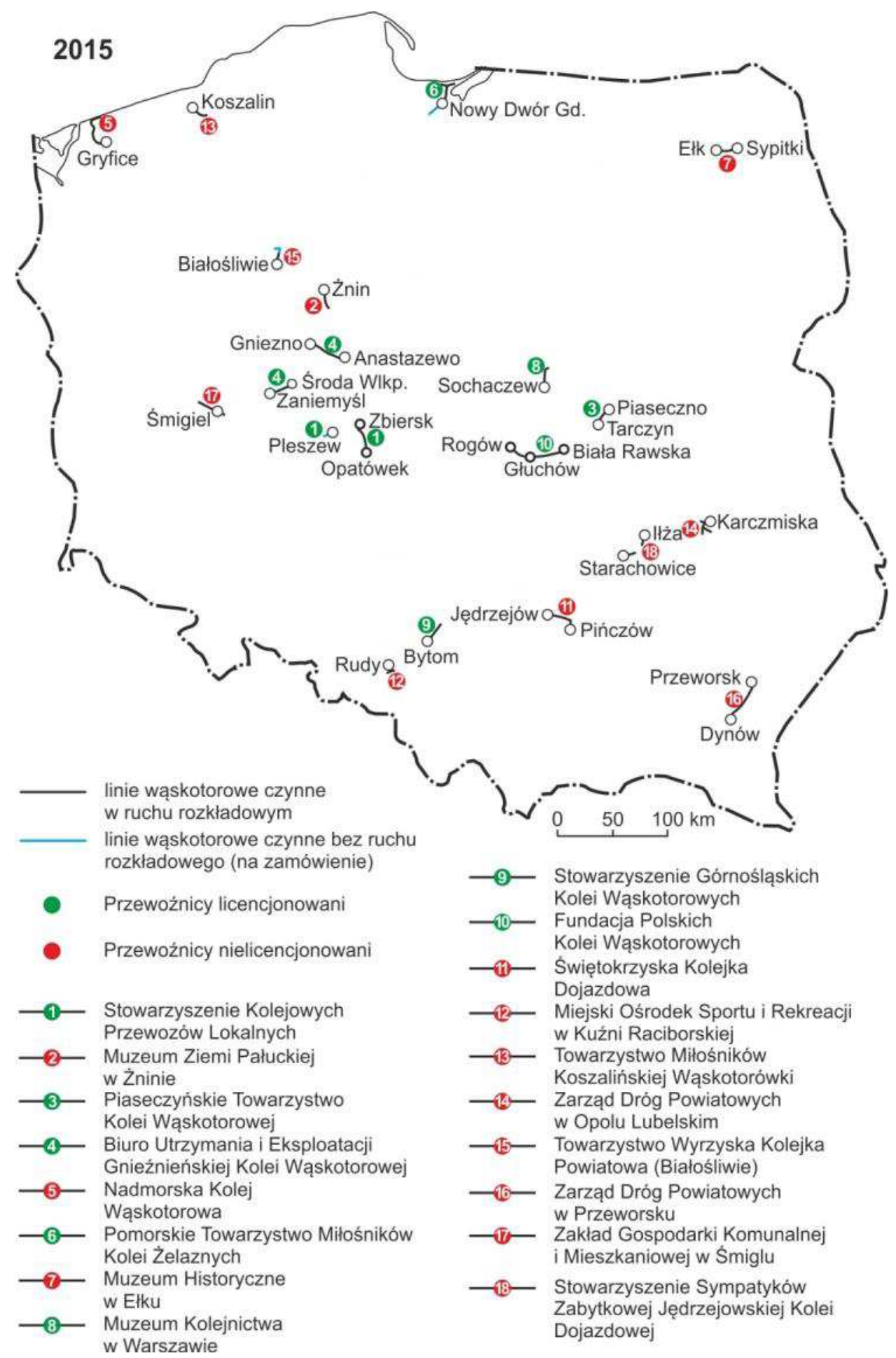

1. Former narrow-gauge railways used by tourists in 2015 


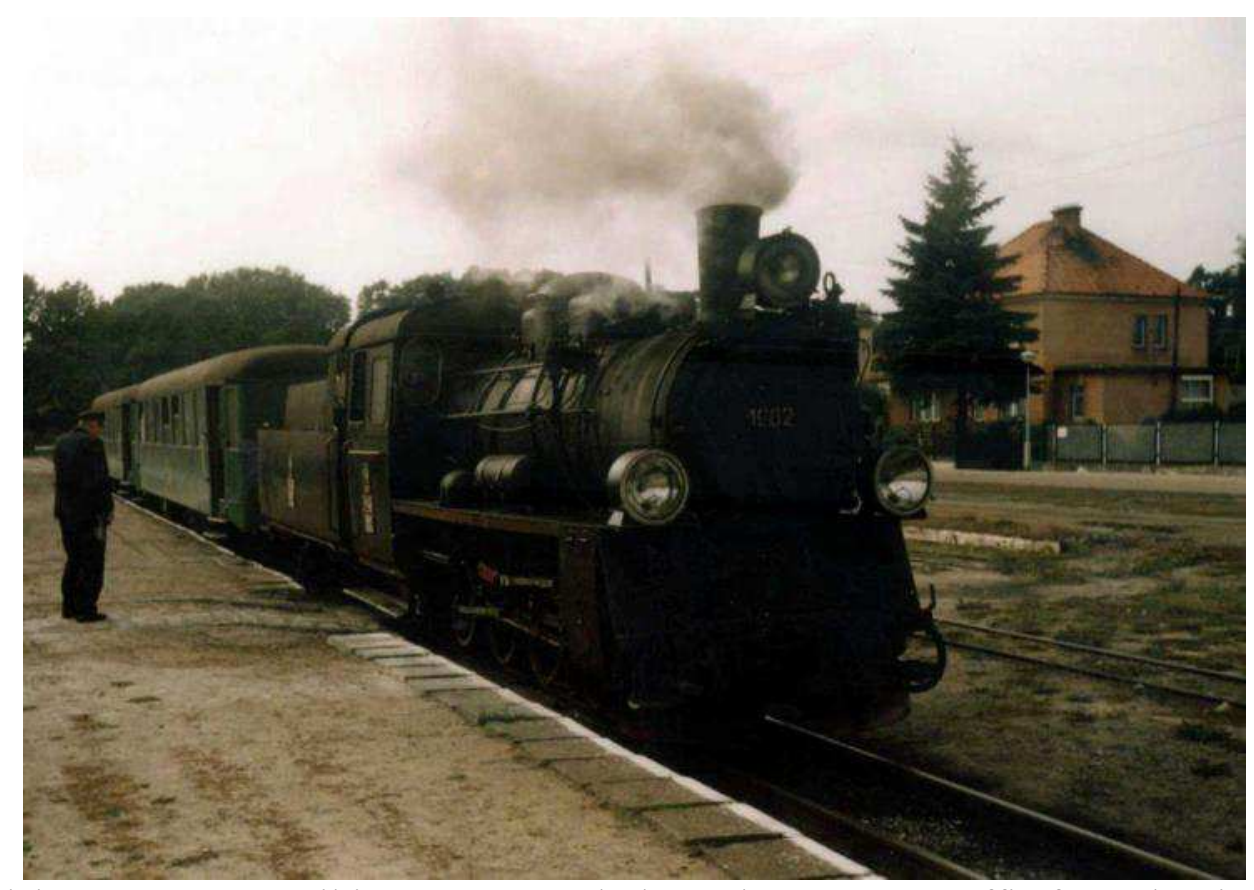

2. Średzka Commuter Rail in 1997, served planned passenger traffic from the sixties and seventies of the twentieth century. Own study

At the beginning of the railway service (also in the area of regular traffic!) local governments often outsourced NGOs. Nowadays, in many cases, the opposite trend can be observed. The service of the nałęczowska, przeworska or śmigielska from the hands of the once real narrow-gauge tycoon - Association of Railways Local Transport from Kalisz (SKPL) took over units subordinate to local governments. However, there is a lack of ideas not only to expand and make the offer more attractive, but also to maintain the level. Very infamous example is Śmigielska Commuter Rail, which is supported by SKPL's traditional role in the transport of tourist passengers and freight. The direct operation by the town council and the Śmigiel municipality resulted in a significant reduction of the offer only to several tourist trips per year. The only way to recapitalize the railway was the sale of a part of rolling stock (similar casus is also observed in Gniezno). The lack of ideas for the use of narrowgauge railways unfortunately lead to their gradual decline. In the next few years, it is expected that some of the low-turn railways managed by local governments or their subsidiaries will be closed. There is a lack of awareness that there is a constant need to spend a lot of money on infrastructure recovery. Hence, for example in the case of the Ełk, Heligoland or Gniezno trains, there was a significant reduction in the operation of the lines, and in the case of the średzka railroad, the total utilization of the only fully loaded efficient steam locomotive.

On the other hand, pathological behavior is reversed - the self-government of the Rewal municipality decisively and unnecessarily over-invested the EU funds in the Seaside NarrowGauge Railway linking Gryfice with Trzesacz, Rewal, Niechorze and Pogorzelica Gryfice. The modernization of rolling stock and the construction of new railway buildings, which are reasonable in use, are justified by the concerns of the authors of the proposal for EU funding under a large question mark. The realization of this project strongly jolted the finances of the community of Rewal, bringing it to the brink of bankruptcy.

Most local governments, however, totally refuse to invest not only in railroad leased but also directly managed by themselves. In addition, the instability of the Polish selfgovernment system, which is expressed inter alia by the discontinuity of power, also imprints on the narrow gauge railway managed by non-governmental organizations. The inequality in 
relation to self-governments of the narrow gauge railways results in minimizing the investment of own funds (directly and as own contributions in subsidized competitions). According to the author, this is a way of avoiding the situation where, once the railroads reach high standards of exploitation and tourism, the local government will solve the operator's contract and, in the framework of political distribution, hand over to the people from their own political background. Seldom, as in the case of the Bytom-Silesian province narrow railway, it is possible to meet with significant support of self-governments, especially in the case of rolling stock repairs, as well as subsidies for train journeys.

However, it can not be ignored that the lovers of railways themselves also contribute to the exclusion of several narrow gauge railways from a group of already existing tourist attractions. The most spectacular example here is the railway leading from Piotrków Trybunalski to Sulejów, which was liquidated as a result of, inter alia, the conflict between the railroad association and the self-government, conservators and railroads. Since the first half of the nineties it was undoubtedly the narrow gauge railway with the greatest tourist potential in the area of the present Łódź province. It was implemented to handle tourists by the specially designated for this purpose the Society of Friends of Narrow-Gauge Railway Piotrków-Sulejów. A similar casus (fortunately without physical liquidation) can be seen in the case of the second narrow gauge railway in Krosniewice. Almost identical scenario took place in the northern part of Mazovia, where the Mława Railway was immobilized in similar circumstances.

\section{Narrow-gauge railways for the use of year-round public transport in tourist areas}

In many countries, even in regions with very high tourist potential, narrow-gauge railways still have their basic function. In Switzerland, they carry out the same transport tasks as normal railways. Technically, they also do not show any significant differences with the 1435 $\mathrm{mm}$ track. In fact, $1 / 3$ of the Swiss rail network $(1700 \mathrm{~km})$ is a private railways narrow gauge railway, which consists of 9 networks and many individual lines. They play an important role in urban agglomerations and are characterized by high frequency of courses. Regional narrow-gauge railways, in contrast to agglomerations, have a somewhat lesser measure and also carry freight on transporters. There are also railways of tourist importance, but they play a different role than in Poland [10]. One of the well-known Swiss narrow-gauge railways still filling all three of the aforementioned roles is the popular alpine Rhätische Bahn [8]. The railway network with a track width of $1000 \mathrm{~mm}$ is $384 \mathrm{~km}$ and is located in the canton of Graubünden. Part of its episodes is included in the UNESCO World Heritage Site. In the German Dresden agglomeration, two narrow-gauge railways have been operating for a number of years, for which the carrier is now a two-way communication company Sächsische Dampfeisenbahngesellschaft mbH (Radebeul Ost-Radeburg) and Weißeritztalbahn (FreitalHainsberg-Kurort Kipsdorf). Their behavior [6] is a response to the crisis of narrow gauge railway observed in Poland in the 1960s and 1970s. Despite the implementation of the economic account in the GDR, the historical role of the narrow-gauge railway has been relatively quickly realized and their significance for the developing tourism is relatively rapid. That is why, in the mid-1970s, it was decided to preserve for eight generations, as monuments of transport and industry history, eight (with a total length of $233 \mathrm{~km}$ ) out of 13 then existing narrow gauge railways in popular tourist destinations. Although these railways are primarily used for tourist use and are operated by steam traction, as well as the other means of transport in the Dresden agglomeration, they operate public transport on a daily basis under contracts with the transport organizer Verkehrsverbund Oberelbe. The Harzer Schmalspurbanen (HSB) Harzer Schmalspurbanen has been preserved as a tourist attraction (Photo 3). A network with a track width of $1000 \mathrm{~mm}$ consists of so called. Harzquerbahn from Wernigerode to Nordhausen $(61 \mathrm{~km})$, branching from it to Brockenbahn $(19 \mathrm{~km})$ and Sektalbahn $(8 \mathrm{~km})$. A 
very interesting solution was introduced in Illefeld-Nordhausen in 2004 - the traffic of urban trams from less than 45,000 inhabitants in Nordhausen [4].

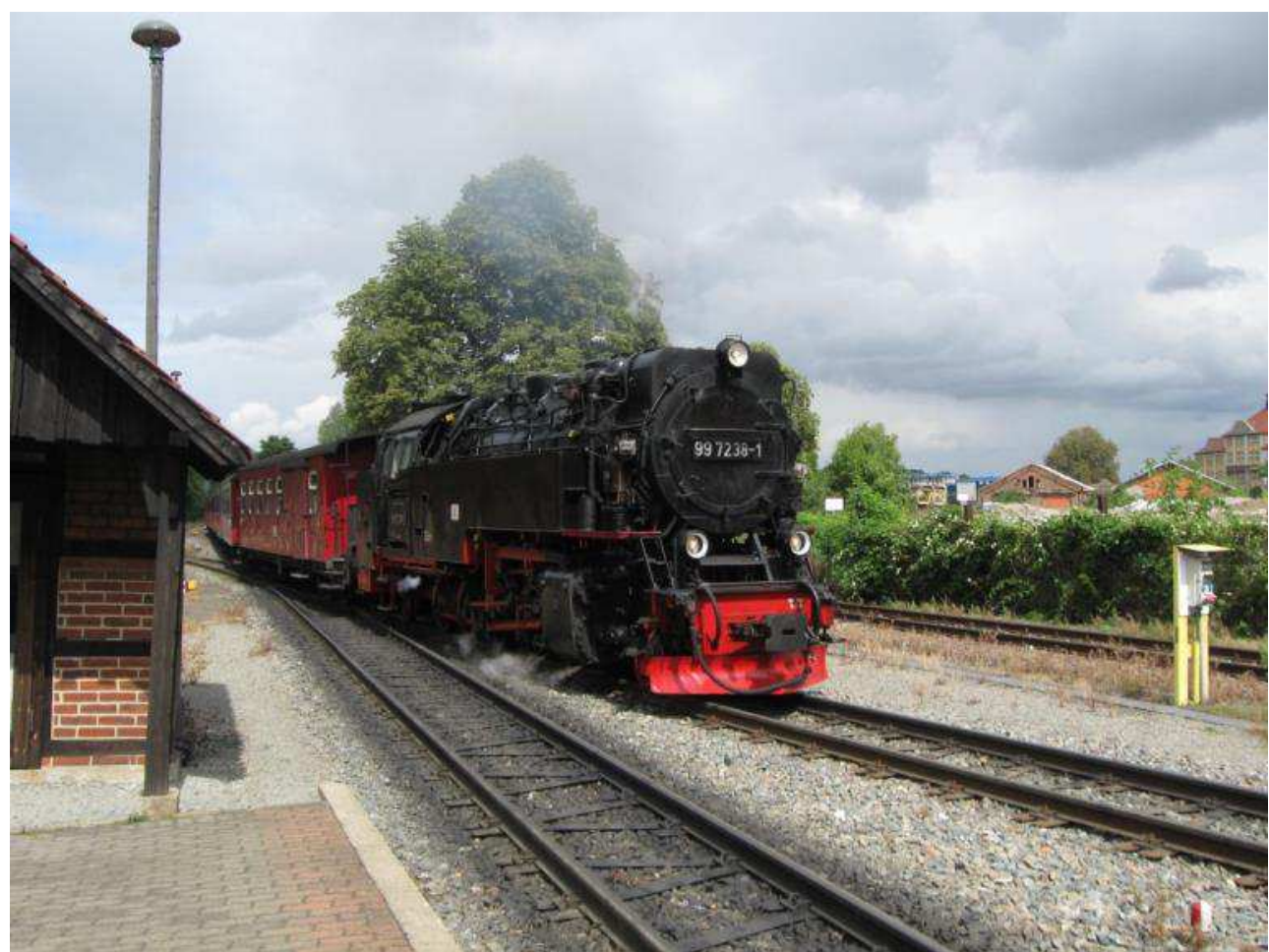

3. The Harz Mountains Railway performs several roles. Steam trains bring tourists to Brocken peak. At the side of motor cars and trams also serve daily local commute. Own study.

An interesting feature is the Czech Jindřichohradecké místní dráhy. While the line from the town of Jindřichův Hradec to Obratan̆ station is primarily a center of daily traffic, the section leading to Nová Bystřice station comes to life in the tourist season. Already in the 1970s, the concept of liquidation of these railways appeared, but luckily, as a result of the fuel crisis, it was considered that transporting cars would not be economical, especially from the energy side. In the early 1990s, the ČSD Czechoslovak State Railways became quite aware of the coming crisis. This resulted in a reduction in investment and a reduction in passenger connections. In 1993, the club was founded in the Czech Republic. He lobbied for the privatization of the railway located in the attractive tourist area and organization of retro trains, and finally proposed a privatization project, which was accepted by the Czech authorities. In addition, he became a founding member of the Jindřichohradecké místní dráhy (JHMD). Under the license of June 1995, the fledgling company began to run historic trains steam trains. Finally, in 1997, Česke Dráhy suspended the carriage on the Jindřichův HradecNová Bystřice line. In January, the line ended, and in March the Czech government finally approved the privatization of the railway and offered to resell them for the nominal price of one crown. The privatization of the narrow gauge railway was effected on 28.02.1998. Regionally distributed regional trains (Photo 4) [10]. 


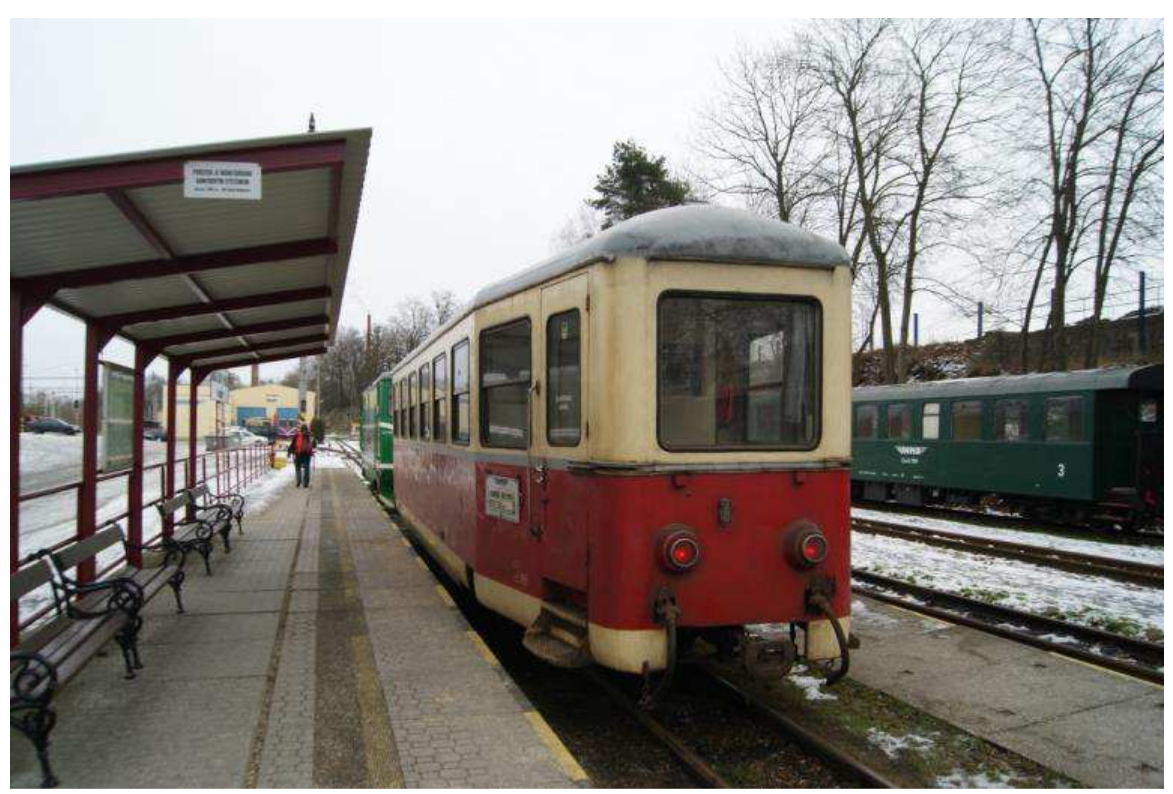

4. On the Czech railway JHMD several dozen people still carry daily passengers to schools and workplaces. Own study.

\section{Adaptation of industrial narrow gauge-railway to tourist function in countries bordering Poland}

A very interesting form of tourist use of the narrow-gauge railway cultural heritage was taken in Kolíno (photo 5). It rebuilt here most of the oldest in the Czech Republic sugar narrowgauge railway. It was built in 1894 and ran for nearly 70 years from the Kolinsko sugar factory to Františkova (Ovčáry), Býchor and Jestřábí Lhota. In order to rebuild it in November 2000 association pro obnovu Kolinské repařské drážky Club was established. It gathered material track and rolling stock belonging to the Ełba sugar earlier narrow gauge railways, and the Regional Operational Program of Social acquired European funds for the reconstruction of railways. On June 23, 2007, the first completed section of the reconstructed railway was $2 \mathrm{~km}$ long. In subsequent years the line was gradually extended (in 2011 to Mlynka). With the start of the 2015 season the railway started driving all the way to Bychor [18].

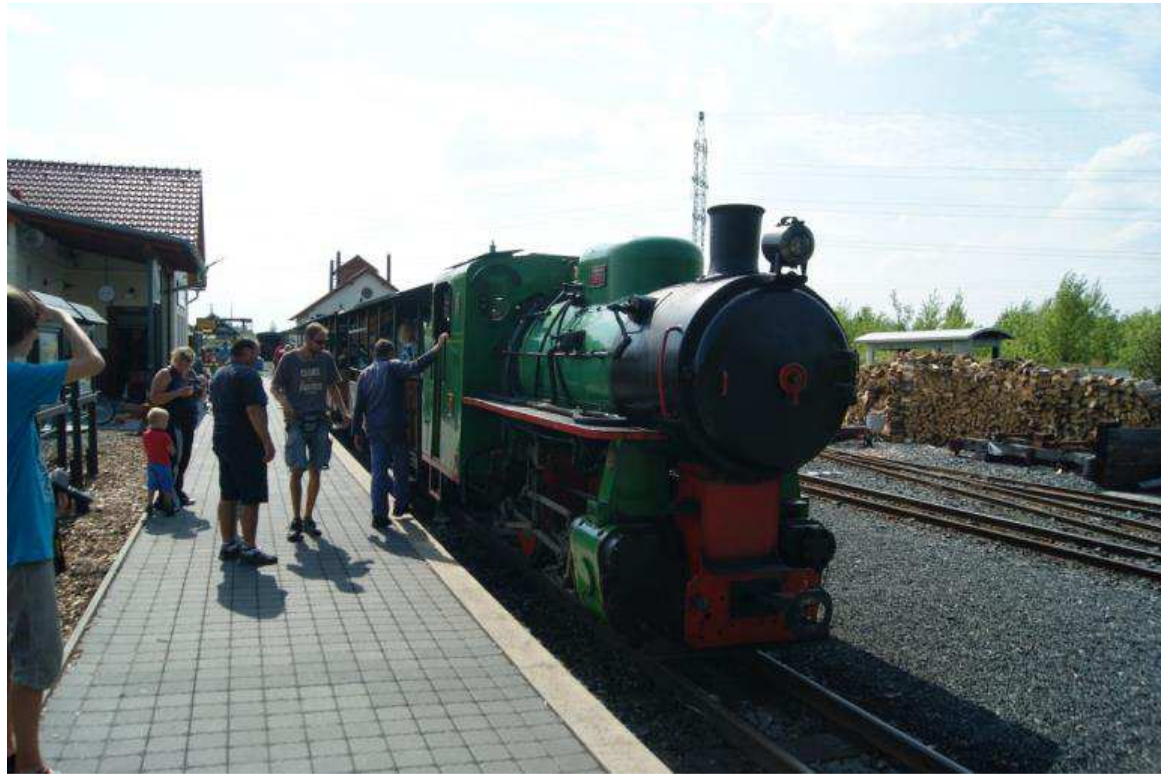

5. Renovated old sugar railway in Kolin attracts crowds.Own study. 
The situation of the narrow-gauge railway in Mladejov was different. The idea of joining the narrow-gauge railway of chamotte mines in Hřebeč and Mladějov was made during the First World War, and it was completed in 1920. In the year 1996 the operation of chamotte plants and their mines was completed. This, however, did not involve stopping traffic on the narrow gauge railway - it was used to carry lunches from the factory canteen in Mladejov to Hřebeč. Occasionally, steam trains were opened for photographers. In 1995, the management of the plant signed a tenancy agreement with the Průmyslových železnic Museum Association for a period of 10 years [19]. The Club decided to relocate its collections to Mladejov in 1995, which has been the object of his interest for many years. On May 1, 1998, the first museum cruise train set off on the trail. In 2005 the MPŽ and the new owner of the chamotte plant did not agree on the extension of the contract and the museum moved to a new location for Zbýšov. In Mladějov there are currently two associations Průmyslové museum Mladějov and Mladějovská průmyslová dráha. In addition to the historic train trip with steam locomotive on the route Mladějov-Nová Ves $(6 \mathrm{~km})$ you can see exhibitions of rolling stock, road and agricultural and construction technology. The rest of Nová Ves-Hřebeč is undergoing work to restore it [19].

Also in Slovakia one can talk about success in adaptation of old industrial railway for tourist purposes. After World War I, two independent railways were established in Orava and Kysucka, ending only $8 \mathrm{~km}$ from each other. In 1928, traffic on the connecting section (unique due to the significant differences in elevation by means of direction changes at intermediate points) was started, and the network was called Kysucko-Orava Forest Railway. In the sixties the regression began and was closed down beyond the most valuable section of the cloud-Beskyd-Tanečník, which in 1972 was considered a national cultural monument. In 1974 the Kysukie Museum in Chadcy took over the line with the intention of building an ethnographic museum along it. Its construction from the beginning was accompanied by the restoration of the railway line to a state of transport. In 1991 it was listed on the UNESCO World Heritage List, and in 1992 an agreement was signed between the museums of Orava and Kysucka for the general renovation of the entire preserved forest railway. In the years 1992-95 the section Kubátkov-Chmúra-Beskyd was reconstructed. The high cost of securing the landslide on the first bend caused the rebuilding of the Beskyd-Tanečník section until 2007 [15][16]. Currently Skansen-1 slopes and Beskyd-Tanečník operate independently. In 2015, motorized dredging courses were introduced in the Skanzen-Beskyd section, making it possible to cross the existing network.

Another example of using the railway as an element of tourist infrastructure in Slovakia is Čiernohronska lesna železnica (Czarnohrońska Forest Railway). Its construction began in 1908 and lasted until the First World War, when the maximum length of the network reached $132 \mathrm{~km}$. In the $1980 \mathrm{~s}$ a decision was taken to completely liquidate the heavily restricted rail network. Fortunately, in 1982 the last fragments were added to the register of monuments. In 1992 the railways were re-launched in the Vydrovská Valley (Photo 6), and a year later, on the main line from Čierneho Balogu to Hronec. In 1995, the local association of municipalities Mikroregión Čierny Hron became the owner and operator of the railway, which in 2001 handed over the role of carrier of the non-profit organization Čiernohronská železnica [1][14]. In 2012, with the support of the European Regional Development Fund - Crossborder Cooperation Program Republic of Hungary-Slovak Republic, the section Čierny Balog-Dobroč $(4 \mathrm{~km})$ was launched. 


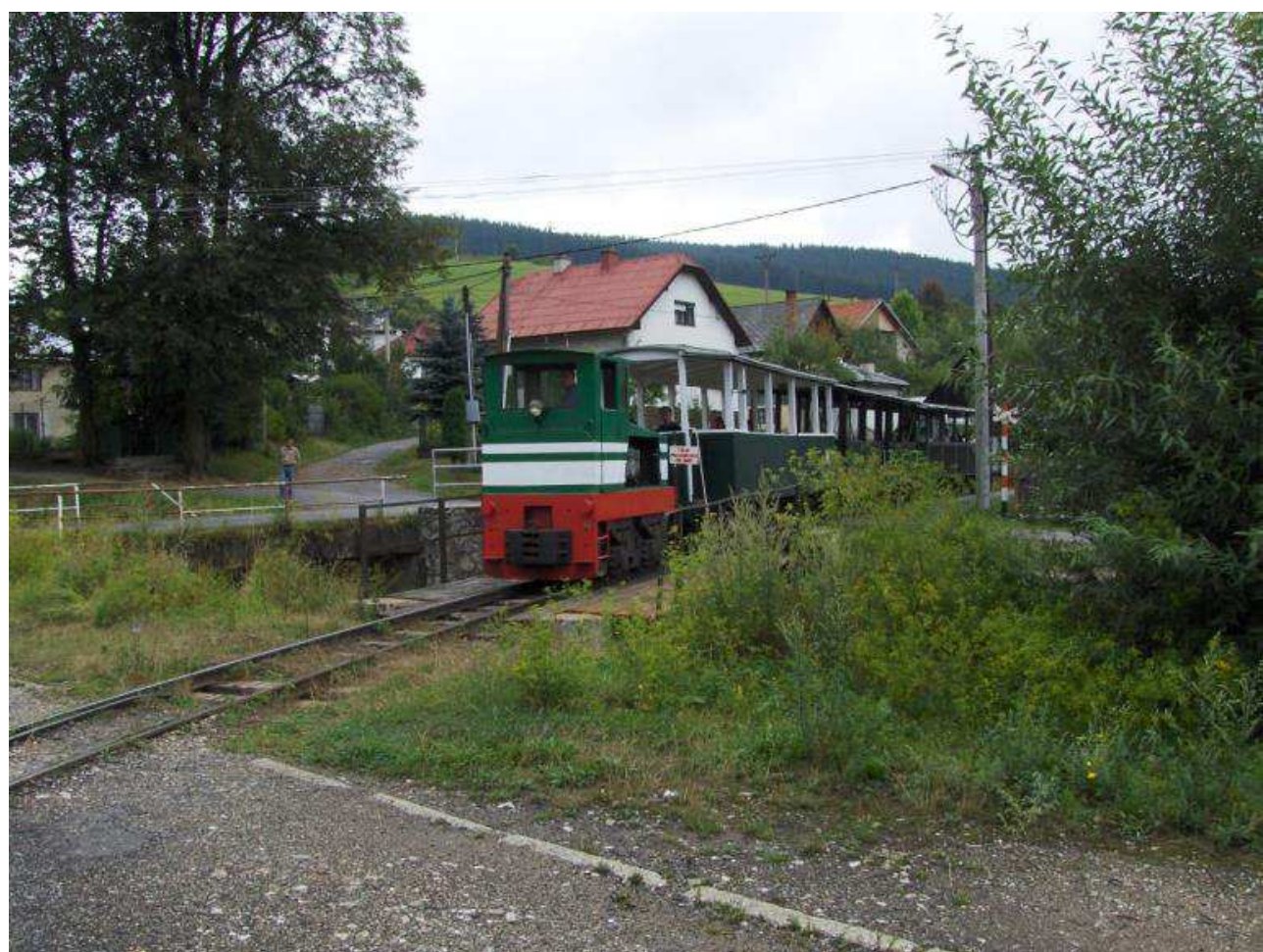

6. The length of the forest railway in the Black Hron valley is constantly increasing. Own study.

Tourist use can be an interesting and lasting form of alternative development of narrow gauge railways - examples of successful adaptations in neighboring countries are confirmed. Some of them are located within walking distance of Poland. In addition to the Kysucka railway, there is a wooden railway from Lusatian Weißwasser (White Water) to Bad Muskau (Mużaków). This railway was built in 1895 to meet the growing demand for transport in the property of Mużaków. The railway network has reached a length of $80 \mathrm{~km}$. In 1951, it was transformed into a forest railway. However, as early as 1978, with the increase in importance of road transport, it was partially liquidated. On the last $12 \mathrm{~km}$ benefited until 1991 Brickyard in Weißwasser. The efforts to preserve Mużakowska Forest Railway as a railway museum were undertaken in the mid-eighties. After 1991, it was possible to rebuild sections of railways and introduce passenger services to parts of the network. Now trains run on two sections connecting the Weißwasser from Bad Muskau and Kromlau [17].

Positive examples of industrial adaptation are also observed in Russia, where the former peat railway was transformed into a private railway museum near Perejesław Zaleski. Its story was started in the 1930s. With the rapid collapse of around 1997, the demand for peat, disintegration and decommissioning of almost all railways with a track width of $750 \mathrm{~mm}$ [7][9][21]. In 2000, the "Perejeslav Railway Museum" took over a non-commercial partnership, with the implementation of highly unprofitable passenger services until 2004, commissioned by the local administration in the Perejeslaw-Kupanskoje section. Two years after their cessation of the $200 \mathrm{~km}$ peat rail network, only $6 \mathrm{~km}$ of the route were abandoned, with the museum planning to dismantle another $4 \mathrm{~km}$ to avoid the steal ... Unlike the previously described railways, it does not carry regular transport [9].

The second, also private museum of narrow gauge railway in Russia, operating in Tjosowo, began to promote its activity only a few years ago. It is based on the still used fragment of the existing narrow gauge railway, which has existed since the 1950s, for the transport of peat [22]. 


\section{To be or not to be - threats and challenges facing tourism based on monuments of narrow-gauge railway in Poland}

One can not resist the impression that in Poland tourist attractions based on the cultural heritage of the railway stood before the Shakespeare dilemma of "to be or not to be". The risks that are discussed below can be determined by the way in which the shingles are tipped:

1. there is a very low level of involvement of non-governmental organizations (as opposed to models adopted in most EU countries) in the conduct of tourist attractions of this type. This is due, among other things. from the claimant attitude towards the companies of the PKP group (former "patron of the living railway open-air museum"), disgusting social work in the Polish People's Republic and low social wellbeing (usually young people with lower managerial qualifications, but with free time, to share their experience or even perform key management functions),

2. conflicts on the lines of railroad enthusiasts are often objects of unbridled human ambition on both sides. On the other hand, they are sometimes caused by the shortsighted policy of the authorities seeing in the railway areas only attractive plots for housing, service or industrial development, and total bypassing their tourist potential.,

3. no possibility to transfer real estate or sell on preferential terms to associations or foundations. In the case of the narrow gauge rail it is much easier to get a part of local governments to take over - so that at least the objects are leased to non-governmental organizations free of charge. The problem, however, is that contracts are usually concluded for short periods of time and do not secure the interests of tenants enough to undertake broader investment than the minimum necessary to ensure safe operation,

4. preservation of the cultural heritage of the railway is very expensive. Firstly, it involves buildings and structures that are large in relation to many other cubic buildings, which is associated with correspondingly higher maintenance and repair costs. The latter are often increased due to the legal protection of the objects through their entry in the register of monuments. Furthermore, the rebuilding and maintenance of historic rolling stock also requires significant resources,

5. there are no public funds available for railway heritage, and these are mostly available for renovation work on historic buildings. Railway facilities must also compete with other monuments, primarily sacred ones, with an older pedigree, which significantly impedes the acquisition of funds for repairs and the adaptation of lotteries to tourist functions. There is also a lack of specialized workshops capable of carrying out the repair of steam trains,

6. given the small wealth of Polish society, it is important to expect that investment in the rolling stock of historic railways and its operation will never be covered by tickets and other revenue..

Further waste of historical objects which may constitute tourist attractions will not only lead to an increase in the distance between Poland and the countries of Western Europe, but also between our country and neighboring countries, also formerly belonging to the socialist bloc. The lack of positive changes and maintaining the regression trend in the coming years will lead to a complete collapse of this sector of the tourism industry. Therefore, it is worth pointing out some potential recommendations that could help to create and develop tourist attractions based on the cultural heritage of the railways:

1. It is necessary to alleviate the regime's ban on free or very preferential transmission of redundant rolling stock and real estate directly to NGOs and returning interests should be adequately covered by the provisions of the notarial acts.

2. it is necessary to reflect on whether narrow-gauge railways, which are not self-managed by local governments, should not be transferred to non-governmental organizations which could provide a stable financing of current maintenance and replacement investments.. 
3. it is necessary to commit the Ministry responsible for transport to social responsibility for its heritage of technical culture and to create financing mechanisms, especially of vehicle repair. In the present situation it is with one of the few ministries which do not offer any, even in the form of subsidies for the so-called. soft actions, support for non-governmental organizations.

\section{Source materials}

[1] Bílek A. Čiernohronská železnica. Růžolící Chrochtík, 2009.

[2] Bebenow F. Turystyka kolejowa w Polsce. WNGiG UAM, 2012, maszynopis pracy magisterskiej.

[3] Bogiazides N., Kotsiou E., Vougioukas M. The Regional Impact of Heritage Railways. 45th Congress of the European Regional Science Association Vrije Universiteit Amsterdam, 2005.

[4] Harrasek A. Dwusystemowy tramwaj w Nordhausen. Technika Transportu Szynowego, 2004, s. 54-55.

[5] Höhmann R. The Future of Heritage Railways and Rail Conservation in Germany. Japan Railway \& Transport Review, 2002, 30, s. 20-22.

[6] Hörz P., Richter M. Preserved as technical monuments, run as tourist attractions: Narrow-gauge railways in the German Democratic Republic. The Journal of Transport History, 2011, 2, s. 192-213.

[7] Корсаков, А. Купанское транспортное управление (история великана), narrow.parovoz.com, 8.07.2015.

[8] Lung E., Knoll O. Regional and Narrow Gauge Railways - Good Practise and Recommendations, 2012, www.southeast-europe.net/document.cmt?id=577, 7.05.2015.

[9] Мясников А. В Переславле есть музей...., Железнодорожное дело, 2006, 2, s. 6-15,

[10] Morel O. Rola kolei wąskotorowych w transporcie Szwajcarii, XVI Dolnośląski Festiwal Nauki we Wrocławiu, 21 września 2013, ww.transport.pwr.wroc.pl/dfn/morel13.pdf, 5.05.2015.

[11] Prochazka P. Význam úzkokolejné železnice Jindřichohradeckých místních drah pro turistický potenciál regionu. Vysoká Škola Polytechnická, Jihlava, maszynopis pracy licencjackiej.

[12] Taylor Z., Ciechański A. Niedawne przekształcenia organizacyjnowłasnościowe przedsiębiorstw transportu kolejowego w Polsce - część II. Przegląd Geograficzny, 2011, 2, s. 205-231.

[13] Ustawa $\mathrm{z}$ dnia 8 września 2000 r. o komercjalizacji, restrukturyzacji i prywatyzacji przedsiębiorstwa państwowego "Polskie Koleje Państwowe"., Dziennik Ustawa RP, 2000, 84, poz. 948.

[14] www.chz.sk, 23.12.2011.

[15] www.kruzok.sk, 23.12.2011.

[16] www.oravamuzeum.sk, 23.12.2011.

[17] www.waldeisenbahn.de/pl, 23.12.2011.

[18] www.zeleznicka.bloudil.cz, 1.07.2015.

[19] www.mladejov.cz, 1.07.2015.

[20] www.mpz.cz, 1.07.2015.

[21] www.kukushka.ru, 5.07.2015.

[22] www.museum-uzd.ru, 5.07.2015. 